\title{
Factors Influence Firm Value
}

\author{
Rona Tumiur Mauli Carolin Simorangkir \\ Universitas Mercu Buana
}

\section{ABSTRACT}

This research aims to know the influence of Working Capital Turnover (WCTO), Total Asset Turnover (TATO) and Debt to Equity Ratio (DER) on the firm value. The population in this research are manufacturing companies listed on the Indonesia Stock Exchange for the period 2013-2017. Sampling method used is purposive sampling. The data analysis technique has been carried out by using multiple linear regressions analysis, and the SPSS program 21. The results of this study indicate that Working Capital Turnover (WCTO) has no effect on firm value, while Total Asset Turnover (TATO) and Debt to Equity Ratio (DER) have an effect on firm value.

Keywords : working capital turnover, total asset turnover, debt to equity ratio, firm value

DOI: $10.7176 / \mathrm{EJBM} / 11-6-09$

\section{INTRODUCTION}

Basically, a company is established as an economy entity that has a goal, either short term goal or long term goal. The short term goal of a company is to maximize profit that is obtained by using all company resources. Meanwhile long term goal of a company that is regarded as the main goal is to maximize firm value (Meythi et al, 2014).

According to Sundari and Utami (2013) Enterprise Value (EV) or known as firm value is an important concept for the investors, because it is an indicator for the market to judge the company overall. Firm value can describe the condition of a firm, so that the investors will see in terms of it's firm value.

Maximum company value can be obtained by implementing financial management function. Financial decision made will affect other financial decisions, so that the effect to company stock price because it will affect firm value (Minanari, 2018).

In this research firm value is measured by using Tobin's q ratio. Tobin's q ratio involves all elements in the balance sheet such as debt, share capital, and total assets owned by the company which is believed able to provide best information in reflecting firm value.

\section{LITERATURE REVIEW}

Signaling Theory

Signaling theory put forward about how a firm should provide signals to the users of financial statements. Signaling theory is a sign given by the company to the investors as instructions about how to look at the company's prospects. The company with profitable prospect will avoid stock sale and will seek new capital with other ways, one of them is by using debt (Brigham and Houston, 2014:186).

\begin{abstract}
Agency Theory
Theory agency is a theory that defines the relationship between principals and agents. Agency theory explains that agency relationship is a contract which one or more principals order other agents to do a service on behalf of the Principal and gives authority to the agents to make the best decision for the Principal. If both parties have the same goals to maximize the firm value, then it is believed that the agent will act in a manner that is in accordance with the interests of the principals (Rinnaya et al., 2016).
\end{abstract}

\section{Firm Value}

According to Harmono (2014:233), firm value is company performance that is reflected by stock price formed by demand and supply in capital market that reflects community assessment to company performance.

\section{Working Capital Turnover (WCTO)}

Kasmir (2017:182) expressed that working capital turnover is one of the ratios to measure or assess the effectiveness of the company's working capital for a certain period.

Total Asset Turnover (TATO)

Syamsudin (2013:62) expressed that Total Asset Turnover is a the level of efficiency of the overall use of company assets in generating certain sales volumes. 
Debt to Equity Ratio (DER)

According to Kamsir (2017:157) Debt to Equity Ratio is a ratio used to assess debt with equity. This ratio is used to know the amount of funds provided by the creditor with company owner.

\section{HYPOTHESIS}

H1: Working capital turnover (WCTO) affects firm value

H2: Total asset turnover (TATO) affects firm value

H3: Debt to Equity Ratio (DER) affects firm value

\section{RESEARCH METHOD}

The data type used in this research is secondary data. The data collection technique is by documentation and literature research. The population in this research are all manufacturing companies (processing industry) registered in Indonesia Stock Exchange from 2013 - 2017. The sampling technique uses purposive sampling method. The sample criteria determined are all manufacturing companies registered continuously in Indonesia Stock Exchange from 2013 - 2017, using rupiah currency from 2013 - 2017, has positive profit and equity (own capital) in financial statements from 2013 - 2017. The total samples used are 47 companies times 5 years of observation which are 235 data which will be used in this research.

The dependent variable used in this research is the firm value measured with the following formula:

$$
Q=\frac{(E M V+D)}{(E B V+D)}
$$

Source: Chung and Pruit (1994)

Explanation:

$$
\begin{aligned}
& \mathrm{Q}=\text { Tobins'Q } \\
& E M V \quad=\text { Equity Market Value } \\
& (E M V=P \text { (closing price } x \text { Qshares) } \\
& E B V \quad=\text { Equity Book Value } \\
& \text { (the difference between total company assets and total debts) }
\end{aligned}
$$$$
D \quad=\text { Debt } / \text { Book Value from Total Debts }
$$

Then the independent variables used in this research are measured with the following formula:

$$
\begin{aligned}
& \text { WCTO }=\frac{\text { Sales }}{\text { Average Working Capital }} \times 100 \% \\
& \text { Source : Kasmir (2017:183) } \\
& \text { TATO }=\frac{\text { Sales }}{\text { Total Assets }} \times 100 \%
\end{aligned}
$$

Source : Fahmi (2014:81)

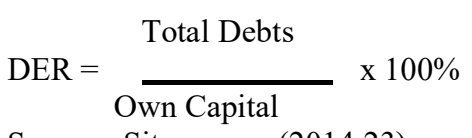

Source : Sitanggang (2014:23)

The method used to analyze data in this research is by using multiple linear regression analysis used to test the influence of several independent variables to dependent variables.

\section{RESULT AND DISCUSSION}

Descriptive Statistics provide new description overall company data seen from the minimum, maximum, average (mean) and standard deviation values. 
Table 1. Descriptive Statistics

Descriptive Statistics

\begin{tabular}{|l|r|r|r|r|r|}
\hline & \multicolumn{1}{|c|}{$N$} & $\begin{array}{c}\text { Minimu } \\
m\end{array}$ & Maximum & \multicolumn{1}{|c|}{ Mean } & Std. Deviation \\
\hline WCTO & 235 &, 59715 & 1762,53786 & 16,237145 & 120,21817734 \\
TATO & 235 &, 30661 & 3,05732 & 1,1678992 &, 50322889 \\
DER & 235 &, 07639 & 2,40153 &, 6950639 &, 49617196 \\
TOBINSQ & 235 &, 30414 & 12,96242 & 2,0794373 & 1,99590965 \\
Valid N & 235 & & & & \\
(listwise) & & & & & \\
\hline
\end{tabular}

Source: Secondary data processed by SPSS 21, 2018

Classic Assumption Test

Data Normality Test uses Kolmogorov-Smirnov statistic test in this research. The basis for decision making is if the test result indicates significant value of Kolmogorov-Smirnov $>0.05$, it means that the data distributes normally. The first Kolmogorov-Smirnov normality test result indicates that the value of Kolmogorov-Smirnov Z value is 1,732 with it's significant 0,005 less than 0,05 or $5 \%(0,005<0,05)$. This thing means that residual data distributes abnormally.

Therefore it can be concluded that the regression model to be analyzed doesn't distribute normally. Thus, to treating the violation of the classic assumption test, namely the normality of the data, the data transformation is carried out by changing the regression model in the semi-log form, which is to the right of the equation (dependent variable) transformed into a natural logarithm $(\mathrm{Ln})$ and the left equation (independent variable). Results after being transformed can be seen in the table below.

Table 2. Data Normality Test Result After Ln Transformation

One-Sample Kolmogorov-Smirnov Test

\begin{tabular}{|ll|r|}
\hline & & $\begin{array}{c}\text { Unstandardized } \\
\text { Residual }\end{array}$ \\
\hline$N$ & Mean & 235 \\
Normal Parameters ${ }^{a, b}$ & Std. &, 0000000 \\
& Deviation &, 71531463 \\
Most Extreme & Absolute &, 064 \\
Differences & Positive &, 062 \\
Kolmogorov-Smirnov Z Z & Negative &,- 064 \\
Asymp. Sig. (2-tailed) &, 983 \\
a. Testdistibution is Normal. &, 289 \\
\hline
\end{tabular}

a. Test distribution is Normal.

b. Calculated from data.

Source: Processed Secondary Data by SPSS 21, 2018

Based on normality test result in Table 2 indicates that Kolmogorov-Smirnov $Z$ value is 0,983 with it's significance 0,289 more than 0,05 or $5 \%(0,289>0,05)$. This means that residual data distributes normally.

Multicollinearity Test aims to test whether the regeresi model found a correlation between independent variables. Multicollinearity test can be seen from the Variance Inflation Factor (VIF) and also Tolerance value. If the VIF value $<10$ or tolerance $>0.10$ means that there is no multicollinearity (Ghozali, 2016: 105). 
Table 3. Multicollinearity Test Result

\begin{tabular}{|l|r|r|}
\hline \multirow{2}{*}{ Model } & \multicolumn{2}{|c|}{ Collinearity Statistics } \\
\cline { 2 - 3 } & Tolerance & \multicolumn{2}{|c|}{ VIF } \\
\hline \multirow{2}{*}{ (Constant) } & & \\
1 1 WCTO &, 966 & 1,035 \\
TATO &, 985 & 1,015 \\
DER &, 959 & 1,043 \\
\hline
\end{tabular}

Source: Processed Secondary Data by SPSS 21, 2018.

The table above shows that the results of the multicollinerity test show tolerance values for each independent variable greater than 0.10 and the results of the Variance Inflation Factor (VIF) also indicate that there are no independent variables that have a VIF value smaller than 10 . So it can be concluded that there is no multicolinerity between independent variables in the regression model.

Autocorrelation test is used to test whether in a linear regression model there is a correlation between confounding errors in period t and period t-1 disturbing errors (Ghozali, 2016: 106). Decision-making is the presence or absence of autocorrelation as follows (Santoso, 2012: 194):

1. The value of $\mathrm{D}-\mathrm{W}$ below -2 means positive autocorrelation.

2. The $\mathrm{D}-\mathrm{W}$ value above +2 means negative autocorrelation is indicated.

3. The $\mathrm{D}-\mathrm{W}$ value between -2 to 2 means that there is no autocorrelation indicated.

Table 4. Autocorrelation Test Result

Model Summary ${ }^{b}$

\begin{tabular}{|l|r|r|r|r|r|}
\hline Model & $R$ & $R$ Square & $\begin{array}{c}\text { Adjusted } R \\
\text { Square }\end{array}$ & $\begin{array}{c}\text { Std. Error } \\
\text { of the } \\
\text { Estimate }\end{array}$ & $\begin{array}{c}\text { Durbin- } \\
\text { Watson }\end{array}$ \\
\hline 1 &, 322 &, 104 &, 092 &, 71994 & 1,459 \\
\hline
\end{tabular}

a. Predictors: (Constant), DER, TATO, WCTO

b. Dependent Variable: Ln_TOBINSQ

Source: Processed Secondary Data by SPSS 21, 2018

Based on the results of the autocorrelation test which can be seen in the table above, it can be explained that the Durbin Watson (DW) number generated is 1,459 . This DW value is between -2 to 2 which means that the DW value is greater than -2 and smaller than 2 , it can be concluded that there is no autocorrelation.

Heteroscedasticity test is to test whether in a linear regression there is a variance of the residual inequality one observation of its variance. A good regression model is homoskedasticity, which is if the residual variance from one observation to another observation remains (Ghozali, 2016: 138). To detect the presence or absence of heteroscedasticity, it is done by looking at the Plot Chart and the Spearman Rho Test. 
Figure 2. Heteroscedasticity Test Result with Scatterplot Graphic

$$
\text { Scatterplot }
$$

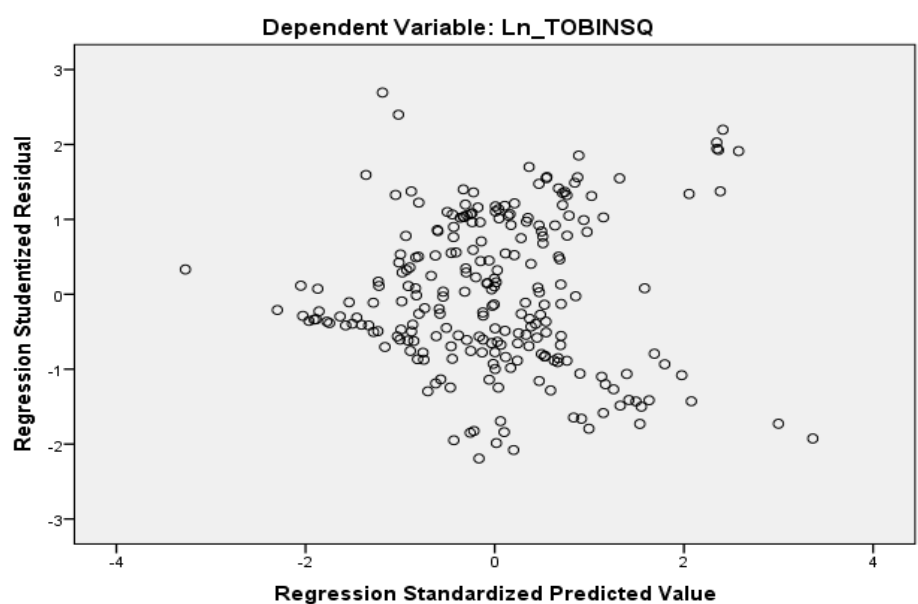

From above scatterplot graphic figure it is seen that the points spread above and below number $0 \mathrm{Y}$ axis, so it can mean that there is no heteroscedasticity.

Based on Spearman's rho test result it can be known from table 5 that significance value or Sig. (2-tailed) of WCTO variable 0,475 , TATO variable 0,731 , and DER variable 0,411 . Because the significance value of those three independent variables are more than 0,05 so that it can be concluded that there is no problem or heteroscedasticity syndrome in regression model.

\section{Table 5. Heteroscedasticity Test Result with Spearman's Rho Test}

\section{Correlations}

\begin{tabular}{|c|c|c|c|}
\hline & & & $\begin{array}{l}\text { Unstandardized } \\
\text { Residual }\end{array}$ \\
\hline $\begin{array}{l}\text { Spear } \\
\text { man's } \\
\text { rho }\end{array}$ & $\begin{array}{l}\text { TATO } \\
\text { DER } \\
\\
\text { Unstandar } \\
\text { dized } \\
\text { Residual }\end{array}$ & $\begin{array}{l}\text { Correlation } \\
\text { Coefficient } \\
\text { Sig. (2-tailed) } \\
N \\
\text { Correlation } \\
\text { Coefficient } \\
\text { Sig. (2-tailed) } \\
N \\
\text { Correlation } \\
\text { Coefficient } \\
\text { Sig. (2-tailed) } \\
N \\
\text { Correlation } \\
\text { Coefficient } \\
\text { Sig. (2-tailed) } \\
N\end{array}$ & $\begin{array}{r}, 047 \\
, 475 \\
235 \\
, 023 \\
\\
, 731 \\
235 \\
, 054 \\
\\
, 411 \\
235 \\
1,000 \\
\\
. \\
235\end{array}$ \\
\hline
\end{tabular}

**. Correlation is significant at the 0.01 level (2-tailed).

*. Correlation is significant at the 0.05 level (2-tailed).

Source: Processed secondary data by SPSS 21, 2018

\section{Hypothesis Testing}

Adjusted R Square (R2) from regression model in this research is 0,092 (table 4) which indicates that the ability of independent variables (WCTO, TATO, DER) at explaining dependent variables such as Firm Value (TOBINSQ) of $9,2 \%$ and the rest $90,8 \%(100 \%-9,2 \%)$ explained by other causes or variables outside the model. 
Table 6. F Test Result

\section{ANOVA $A^{a}$}

\begin{tabular}{|l|r|r|r|r|r|}
\hline Model & $\begin{array}{c}\text { Sum of } \\
\text { Squares }\end{array}$ & $d f$ & $\begin{array}{c}\text { Mean } \\
\text { Square }\end{array}$ & $F$ & Sig. \\
\hline $\begin{array}{l}\text { Regressio } \\
n\end{array}$ & 13,871 & 3 & 4,624 & 8,920 &, $000^{b}$ \\
$1 \quad$ Residual & 119,732 & 231 &, 518 & & \\
$\quad$ Total & 133,603 & 234 & & & \\
\hline
\end{tabular}

a. Dependent Variable: Ln_TOBINSQ

b. Predictors: (Constant), DER, TATO, WCTO

Source: Processed secondary data by SPSS 21, 2018

$\mathrm{F}$ Test result in this research obtained $\mathrm{F}$ count 8.920 with a significant value of 0,000 smaller than the significant limit of 0.05 , the regression model used is correct and it can be said that WCTO, TATO and DER jointly influence the value of the company.

Multiple linear regression analysis was used to determine the effect of Working Capital Turnover (WCTO), Total Asset Turnover (TATO) and Debt to Equity Ratio (DER) on Firm Value. By looking at table 7 the results of multiple linear regression analysis, the equation in this research are:

Ln_TOBINSQ $=0.141+0,000 \mathrm{WCTO}+0,409$ TATO $-0,284$ DER

Table 7. T Test Result and Multiple Linear Regression Analysis

\begin{tabular}{|c|c|c|c|c|c|c|c|}
\hline \multicolumn{8}{|c|}{ Coefficients $^{a}$} \\
\hline \multirow[t]{2}{*}{ Model } & \multicolumn{2}{|c|}{$\begin{array}{c}\text { Unstandardized } \\
\text { Coefficients }\end{array}$} & \multirow{2}{*}{$\begin{array}{c}\text { Standardiz } \\
\text { ed } \\
\text { Coefficient } \\
\text { S } \\
\text { Beta }\end{array}$} & \multirow[t]{2}{*}{$t$} & \multirow[t]{2}{*}{ Sig. } & \multicolumn{2}{|c|}{ Collinearity Statistics } \\
\hline & $B$ & $\begin{array}{l}\text { Std. } \\
\text { Error }\end{array}$ & & & & Tolerance & $V I F$ \\
\hline $\begin{array}{l}\text { (Consta } \\
n t)\end{array}$ &, 141 &, 131 & & 1,079 & 282 & & \\
\hline 1 WCTO &, 000 &, 000 &,- 039 &,- 618 &, 537 & 966 & 1,035 \\
\hline TATO &, 409 & 094 & 272 & 4,342 &, 000 & 985 & 1,015 \\
\hline$D E R$ &,- 284 & 097 &,- 186 & $-2,929$ &, 004 & ,959 & 1,043 \\
\hline
\end{tabular}

a. Dependent Variable: Ln_TOBINSQ

Source: Processed secondary data by SPSS 21, 2018

\section{RESULT AND DISCUSSION}

\section{The Effect of Working Capital Turnover (WCTO) on Company Values}

Based on the results of hypothesis testing (table 7) that has been done shows that Working Capital Turnover (WCTO) has $t$ count of -0.618 with a significant value of 0.537 which is greater than the significant level of 0.05 $(0.537>0.05)$. Based on these values, it can be concluded that the hypothesis $1(\mathrm{H} 1)$ which states that Working capital turnover (WCTO) affects the value of the company is rejected.

The influence of the Working capital turnover (WCTO) variable in this research is not because the Working capital turnover (WCTO) value does not affect the increase in stock prices and because the Working capital turnover (WCTO) value is influenced by several items on the balance sheet, such as inventory turnover, accounts receivable and balance company cash. Where these items have different proportions in each company characteristic. 


\section{The Effect of Total Asset Turnover (TATO) on Company Values}

Based on the results of hypothesis testing (table 7) that has been done shows that Total Asset Turnover (TATO) has a $t$ count of 4.342 with a significant value of 0.000 which is greater than a significant level of $0.05(0,000$ $<0.05)$. Based on these values, it can be concluded that hypothesis 2 (H2) states that Total asset turnover (TATO) affects the value of the company received. The higher total asset turnover (TATO), the higher the value of the company.

\section{The Effect of Debt To Equity Ratio (DER) on Company Values}

Based on the results of testing the hypothesis (table 7) that has been done shows that the Debt to Equity Ratio (DER) has a t count of -2.929 with a significant value of 0.004 which is smaller than the significant level of 0.05 $(0.004>0.05)$. Based on these values, it can be concluded that hypothesis 3 (H3) which states that the Debt to equity ratio (DER) affects the value of the company received. The higher the Debt to Equity Ratio (DER), the lower the value of the company.

\section{CLOSING}

Conclusion

1. The results of the research indicate that the WCTO does not affect the value of the company.

2. The results of the research indicate that TATO has an effect on the value of the company.

3. The results of the research show that DER affects the value of the company.

\section{Suggestion}

It is recommended for further research to add or replace several other measurement proxies in the assessment of financial performance that have an influence on firm value. And it is suggested for further research to expand the scope of research not only in manufacturing companies to obtain accurate research results.

\section{BIBLIOGRAPHY}

Afrilian, D. Y. (2013). Pengaruh Faktor Fundamental dan Teknikal Terhadap Nilai Perusahaan (Studi Pada Perusahaan Manufaktur yang Terdaftar di Bursa Efek Indonesia Pada Tahun 2009-2012). Jurnal Fakultas Ekonomi dan Bisnis Universitas Brawijaya Malang.

Aggarwal, Divya, \& Padhan, P. C. (2017). Impact of Capital Structure on Firm Value:Evidence from Indian Hospitality Industry. Theoretical Economics Letters, 7, 982-1000.

Apritasari, W. R., \& Oetomo, H. W. (2013). Pengaruh financial Leverage, ITO, WCTO Terhadap Nilai Perusahaan Pada Perusahaan Farmasi Swasta. Jurnal Ilmu \& Riset Manajemen, 2(12).

Astutik, D. (2017). Pengaruh Aktivitas Rasio Keuangan Terhadap Nilai Perusahaan (Studi Pada Industri Manufaktur). Jurnal STIE SEMARANG, 9(1), ISSN 2085-5656.

Brigham, Eugene F. dan Joel F. Houston. (2014). Dasar-Dasar Manajemen Keuangan. Penerjemah: Ali Akbar Yulianto. Edisi 11. Buku 2. Jakarta: Salemba Empat.

Cheryta, A. M, Moeljadi., \& Indrawati, N. K. (2017). The Effect of Leverage, Profitability, Information Asymmetry, Firm Size on Cash Holding and Firm Value of Manufacturing Firms Listed at Indonesian Stock Exchange. International Journal of Research in Business Studies and Management, 4(4), 21-31.

Chotimah, C., \& Amanah, L. (2013). Analisis Rasio Keuangan Terhadap Return Saham Dan Nilai Perusahaan. Jurnal Ilmu \& Riset Akuntansi, 2(12).

Chung, K.H and Pruitt, S.W, (1994). A Simple Approximation of Tobin's q, Financial Management, 23(70-74).

Fahmi, Irham. (2014). Manajemen Keuangan Perusahaan Dan Pasar Modal. Jakarta: Mitra Wacana Media.

Gamayuni, R. R. (2012). Relevansi Kinerja Keuangan, Kualitas Laba, Intangible Asset, dengan Nilai Perusahaan. Trikonomika, 11(2), 119-136, ISSN 1411-514X.

Ghozali, Imam. (2016). Aplikasi Analisis Multivariat dengan Program IBM SPSS 23. Edisi 8. Semarang: Badan Penerbit Universitas Diponogoro.

Harahap, Sofyan Syafri. (2015). Analisis Kritis Atas Laporan Keuangan. Cetakan Kedua Belas. Jakarta: PT. Raja Grafindo Persada

Hariati, Isnin., dan Rihatiningtyas, Y. W. (2015). Pengaruh Tata Kelola Perusahaan Dan Kinerja Lingkungan Terhadap Nilai Perusahaan. Simposium Nasional Akuntansi XVIII Medan.

Harmono. (2014). Manajemen Keuangan : Berbasis Balanced Scorecard Pendeketan Teori, Kasus dan Riset Bisnis. Jakarta: PT Bumi Aksara.

Haryati, W., \& Ayem, S. (2014). Pengaruh Return On Assets, Debt To Equity Ratio, Dan Earning Per Share Terhadap Nilai Perusahaan (Studi Kasus Pada Perusahaan Food And Beverages Yang Terdaftar Di BEI Periode 2009-2011). Jurnal Akuntansi, 2(1). 
Hermawan, S., \& Maf'ulah, A. N. (2014). Pengaruh Kinerja Keuangan Terhadap Nilai Perusahaan Dengan Pengungkapan Corporate Social Responsibility Sebagai Variabel Pemoderasi. Jurnal Dinamika Akuntansi, 6(2), 103-118, ISSN 2085-4277.

Hery. (2015). Pengantar Akuntansi. Jakarta: PT. Grasindo.

Hoque, Jahirul., Hossain, A., \& Hossain, K. (2014). Impact Of Capital Structure Policy On Value Of The Firm-A Study On Some Selected Corporate Manufacturing Firms Under Dhaka Stock Exchange. ECOFORUM, Vol 3 , Issue 2(5).

https://finance.detik.com, 2014 (di akses 25 April 2018).

http://investasi.kontan.co.id, 2016 (di akses 25 April 2018).

https://katadata.co.id, 2017 (di akses 25 April 2018).

https://www.cnnindonesia.com, 2017 (di akses 25 April 2018).

Itsnaini, H. M., \& Subardjo, A. (2017). Pengaruh Profitabilitas dan Solvabilitas Terhadap Nilai Perusahaan Yang Dimoderasi Corporate Social Responsibility. Jurnal Ilmu dan Riset Akuntansi, 6(6), ISSN : 2460-0585.

Jensen, M. and Meckling, W., (1976). "Theory of the firm: Managerial Behavior Agency Cost, and Ownership Structure", Journal of Finance Economics, 3, pp. 305-360.

Jumingan. (2014). Analisis Laporan Keuangan. Jakarta: Bumi Aksara.

Kasmir. (2016). Pengantar Manajemen Keuangan. Edisi Kedua. Jakarta: Prenadamedia Group.

Kasmir. (2017). Analisis Laporan Keuangan. Jakarta: PT. Raja Grafindo Persada.

Mayarina, N. A., \& Mildawati, T. (2017). Pengaruh Rasio Keuangan Dan FCF Terhadap Nilai Perusahaan: Kebijakan Dividen Sebagai Pemoderasi. Jurnal Ilmu dan Riset Akuntansi, 6(2), 576-596, ISSN : 2460-0585.

Mayogi, Dien Gusti dan Fidiana. (2016). Pengaruh Profitabilitas, Kebijakan Dividen, dan Kebijakan Utang Terhadap Nilai Perusahaan. Jurnal Ilmu dan Riset Akuntansi, 5(1), ISSN : 2460-0585. Sekolah Tinggi Ilmu Ekonomi Indonesia (STIESIA) Surabaya.

Meythi., Oktavianti., Martusa, R. (2014). Nilai Perusahaan: Dampak Interaksi Antara Profitabilitas Dan Risiko Finansial Pada Perusahaan Manufaktur. Jurnal Keuangan dan Perbankan, 18(1), 40-51.

Minanari. (2018). Pengaruh Profitabilitas, Manajemen Laba Dan Kebijakan Deviden Terhadap Nilai Perusahaan (Studi Empiris Pada Perusahaan Manufaktur Yang Terdaftar Di Bursa Efek Indonesia Periode 2015 - 2016). Jurnal Profita, 11(1).

Musthafa. (2017). Manajemen Keuangan. Yogyakarta: CV. Andi Offset.

Prasetiono \& Utami, R. B. (2016). Analisis Pengaruh TATO, WCTO Dan DER Terhadap Nilai Dengan ROA Sebagai Variabel Intervening (Studi Pada Perusahaan Manufaktur Yang Terdaftar Di Bursa Efek Indonesia Periode Tahun 2009-2013). Jurnal Studi Manajemen \& Organisasi, 13, $28-43$.

Purnaya, I Gusti Ketut. (2016). Ekonomi dan Bisnis. Yogyakarta: CV. Andi Offset.

Rahardjo, S. N., \& Jusriani, I. F. (2013). Analisis Pengaruh Profitabilitas, Kebijakan Deviden, Kebijakan Utang, Dan Kepemilikan Manajerial Terhadap Nilai Perusahaan (Studi Empiris Pada Perusahaan Manufaktur Yang Terdaftar Di Bursa Efek Indonesia Periode 2009-2011). Diponogoro Journal Of Accounting, 2(2), 110, ISSN 2337-3806. http://ejournal-s1.undip.ac.id/index.php/accounting

Rinnaya, I. Y., Andini. R., \& Oemar, A. (2016). Pengaruh Profitabilitas, Rasio Aktivitas, Keputusan Pendanaan Keputusan Investasi Terhadap Nilai Perusahaan (Studi Empiris Pada Perusahaan Manufaktur Yang Terdaftar Di BEI Tahun 2010-2014). Journal Of Accounting, 2(2).

Santoso, Singgih. (2012). Analisis SPSS pada statistik parametik. Jakarta : PT. Elex Media Komputindo.

Sawir, Agnes. (2012). Analisis Kinerja Keuangan dan Perencanaan Keuangan Perusahaan. Jakarta: Gramedia Pustaka Utama.

Siswoyo, E., \& Oetomo, H. W. (2012). Analisis Rasio Aktivitas Terhadap Nilai Perusahaan Yang Diukur Dengan Metode Tobin's Q. Jurnal Ilmu \& Riset Manajemen, 1(9).

Sitanggang, J. P. (2014). Manajemen Keuangan Perusahaan. Jakarta:Mitra Wacana Media.

Stiyarini \& Santoso, B. H. (2016). Pengaruh Kinerja Keuangan Terhadap Nilai Perusahaan Pada Perusahaan Jasa Telekomunikasi. Jurnal Ilmu dan Riset manajemen, 5(2), ISSN 2461-0593.

Sucuaci, William \& Jay Mark Cambarihan. (2016). Influence of Profitability to the Firm Value of Diversified Companies in the Philippines. Journal of Accounting and Finance Research, 5(2).

Sudana, I Made. (2015). Teori dan Praktik Manajemen Keuangan Perusahaan. Jakarta : Erlangga.

Utami, W. \& Sundari, W. T. (2013). Pengaruh Kinerja Keuangan Terhadap Nilai Perusahaan Dengan Kebijakan Dividen. Jurnal MIX, 3(3).

Syamsudin, Lukman. (2013). Manajemen Keuangan Perusahaan. Jakarta: PT. Gramedia Pustaka Utama.

Wolk et. al. (2000). Accounting Theory: A Conceptual Insititusional Approach. Fifth Edition. South-Western College Publishing.

Yegon, Charles Kiprotich., Kiprono, Kirui Joseph., \& Willy, Chepkutto. (2014). Working Capital Management and Corporate Financial Performace : Eviidance from Panel Data Analysis of Selected Quoted Tea Companies in Kenya. Research Journal of Finance and Accounting, 5(5). 
Vol.11, No.6, 2019

$\underline{\text { www.idnfinancials.com }}$

www.idx.co.id

www.sahamok.com 